\title{
Silagens de grãos de milho puro e com adição de grãos de soja, de girassol ou uréia
}

\author{
Clóves Cabreira Jobim ${ }^{(1)}$, Lauzimery Lombardi(1), Francisco Assis Fonseca de Macedo(1) \\ e Antonio Ferriani Branco ${ }^{(1)}$
}

(1)Universidade Estadual de Maringá, Departamento de Zootecnia, Av. Colombo, no 5790, CEP 87020-900 Maringá, PR. E-mail: ccjobim@uem.br, lylombardi@yahoo.com.br, fafmacedo@uem.br, afbranco@uem.br

\begin{abstract}
Resumo - O objetivo deste trabalho foi avaliar a composição química e a estabilidade em aerobiose de silagens de grãos de milho, ensilados com adição de soja crua, girassol ou uréia. Em delineamento inteiramente casualizado, com quatro repetições, foram avaliados os tratamentos: grãos de milho; grãos de milho mais grãos de soja; grãos de milho mais grãos de girassol; e grãos de milho mais uréia. Foram utilizados, como silos experimentais, tonéis de plástico com capacidade para $200 \mathrm{~kg}$, que permaneceram vedados por nove meses. Avaliaram-se: a composição química, a degradabilidade ruminal da matéria seca e da proteína bruta, o desaparecimento do amido no rúmen e a estabilidade aeróbia das silagens. Todos os tratamentos tiveram efeito sobre a degradabilidade efetiva da matéria seca e da proteína bruta, e também sobre a composição química das silagens, especialmente nos teores de proteína bruta e extrato etéreo. A adição de $20 \%$ de grãos de soja, de girassol ou uréia ( $1 \%$ ), na silagem de grãos de milho, melhora sua composição químico-bromatológica, porém reduz a degradabilidade efetiva da matéria seca e da proteína bruta. A adição de uréia à silagem de grãos úmidos de milho diminui as perdas de matéria seca e melhora a estabilidade em aerobiose.
\end{abstract}

Termos para indexação: composição químico-bromatológica, degradabilidade ruminal, digestão de amido, energia, estabilidade aeróbia, proteína bruta.

\section{Quality of corn grain silage added with soybean, sunflower or urea}

\begin{abstract}
The objective of this work was to evaluate the chemical composition and aerobic stability of corn grain silage, added with crude soybean, sunflower or urea. The following treatments, arranged in a completely randomized design, with four replications, were evaluated: corn grain; corn grain plus soybean grain; corn grain plus sunflower grain; and corn grain plus urea. Plastic barrels with $200 \mathrm{~kg}$ of capacity were used as experimental silos and kept closed for nine months. Chemical composition, dry matter and crude protein ruminal degradability, starch ruminal disappearance, and the aerobic stability of silages were evaluated. The addition of soybean, sunflower or urea on silages influenced the effective degradability of dry matter and crude protein, and the chemical composition, especially in relation to crude protein and ether extract contents. The addition of $20 \%$ soybean, sunflower or urea (1\%) in corn grain silage improves chemical composition, but decreases the effective degradability of dry matter and crude protein. Urea addition to moist corn grain silage reduces losses on dry matter and improves the aerobic stability.
\end{abstract}

Index terms: chemical composition, ruminal degradability, starch digestibility, energy, aerobic stability, crude protein.

\section{Introdução}

O uso de ração concentrada, na alimentação de ruminantes, aumenta a ingestão de proteína e energia e atende melhor às exigências nutricionais dos animais, quando comparado ao consumo exclusivo de forragens. Geralmente, grãos são incluídos nas dietas pelo uso de concentrados, que possuem grandes quantidades de carboidratos solúveis de fácil digestão e aumentam a disponibilidade de energia metabolizável aos animais (Theurer, 1999).

Estudos com silagem de grãos úmidos de milho têm evidenciado que há aumento na digestibilidade da matéria seca, principalmente graças ao aumento na digestão do 
amido, principal componente do grão de milho (Jobim et al., 1997). De acordo com Reis et al. (2001) e Berndt et al. (2002), esse tipo de silagem é vantajosa em termos nutricionais, pois aumenta a eficiência de conversão alimentar.

Em revisão, Jobim \& Reis (2001) relataram que o uso do milho úmido para silagem é vantajoso em relação ao uso do grão seco, pois a digestibilidade da matéria seca é aumentada. A maior digestibilidade do amido de grãos ensilados deve-se, sobretudo, à fragilização da matriz protéica que recobre os grãos de amido do endosperma periférico (Demarquilly, 1996).

A impossibilidade de formulação de concentrados antecipadamente é uma desvantagem da silagem de grãos úmidos (Jobim et al., 2001), por não poder ser armazenada a mistura pronta, para usos posteriores. Esse fato faz com que seja necessário misturá-la, diariamente, aos demais ingredientes da dieta, antes de seu fornecimento aos animais. Assim, a ensilagem de grãos úmidos de milho com aditivos que elevem o valor nutricional, especialmente no que se refere ao teor de proteína bruta e energia, é de grande interesse, pois pode disponibilizar ao produtor uma silagem com valor nutricional semelhante ao dos concentrados comerciais. Nesse contexto, Jobim et al. (2002) realizaram estudos que comprovam a viabilidade da adição de grãos de soja na ensilagem de grãos úmidos de milho, com resultados positivos, pois observaram aumento no teor de proteína bruta de silagens de grãos úmidos de milho, sem prejuízos para a conservação da silagem. A soja em grão pode tornar-se uma fonte de proteína de baixo custo, por apresentar preço mais acessível em relação ao farelo de soja desengordurado.

O cultivo do girassol (Helianthus annus L.) vem se expandindo, contudo sua produção é direcionada para a extração de óleo dos grãos, em que o subproduto tem sido utilizado na alimentação animal na forma de farelo.

Outra possibilidade de se elevar o teor de proteína bruta de silagens de grãos úmidos de milho é a adição de uréia. Embora a adição de uréia em silagens seja prática corrente, não foram encontrados registros de estudos que a usem em silagem de grãos úmidos de milho.

O presente trabalho teve como objetivo avaliar a composição químico-bromatológica e a estabilidade em aerobiose das silagens de grãos de milho, ensiladas com a adição de soja crua, girassol ou uréia.

\section{Material e Métodos}

$\mathrm{O}$ experimento foi conduzido na Universidade Estadual de Maringá (UEM), no Campus do Arenito, em Cidade Gaúcha, PR, e na Fazenda Experimental de Iguatemi, também pertencente à UEM.

O plantio do milho foi realizado em 3 de novembro de 2004, na área do Campus do Arenito. O híbrido de milho utilizado foi o AG 405, adubado com $500 \mathrm{~kg} \mathrm{ha}^{-1}$ da fórmula NPK 4-20-20, no plantio, e adubação de cobertura com $100 \mathrm{~kg} \mathrm{ha}^{-1} \mathrm{de}$ N. A colheita foi efetuada no dia 4 de março de 2005, quando o milho atingiu o ponto adequado para ensilagem dos grãos, com cerca de $68 \%$ de matéria seca. O milho foi debulhado em trilhadeira estacionária, ligada à tomada de força do trator e, posteriormente, foi triturado em peneira de $8 \mathrm{~mm}$.

Foram avaliados os seguintes tratamentos, arranjados em delineamento experimental inteiramente casualizado, com quatro repetições: silagem de grãos úmidos de milho (SGM); $\mathrm{SGM}+20 \%$ de soja crua (SMS); $\mathrm{SGM}+$ $20 \%$ de grãos de girassol (SMG) e SGM + 1\% de uréia (SMU).

No momento do processamento dos grãos, triturados em peneira de $8 \mathrm{~mm}$, foi feita a adição dos grãos de soja ou de girassol, de acordo com os tratamentos, e foram realizadas as amostragens dos alimentos ensilados para análises químicas. A uréia granulada foi adicionada no momento da ensilagem, após o processamento dos grãos de milho. Depois de processados, os grãos foram colocados em um misturador de ração, com capacidade de $500 \mathrm{~kg}$, para melhor homogeneização com os aditivos.

Durante o enchimento e compactação dos silos experimentais, foi adicionado, em todos os tratamentos, o inoculante enzimo-bacteriano Katec, na dosagem recomendada pelo fabricante.

As silagens foram confeccionadas em tambores de plástico, com capacidade de 200 L. Após compactação e vedação adequada, os tambores foram armazenados a céu aberto, cobertos com lona de plástico. O material ficou armazenado durante nove meses, e depois foi aberto.

Após a abertura dos silos, as amostras das silagens foram submetidas à secagem em estufa de ventilação forçada $\left(55^{\circ} \mathrm{C}\right.$ por 72 horas) e, logo após, foram moídas ( $5 \mathrm{~mm}$ ), para posterior análise. Determinaram-se os teores de matéria seca (MS), proteína bruta (PB), extrato etéro (EE) e matéria mineral (MM) (Silva \& Queiroz, 2002). A matéria orgânica (MO) também foi estimada. 
O teor de amido foi determinado pelo método de Poore, adaptado por Pereira \& Rossi (1994).

A avaliação da estabilidade aeróbia das silagens foi feita segundo Kung Júnior (2001), com o diferencial de não ter havido controle de temperatura ambiental. As amostras foram mantidas em sala de laboratório, sujeita a variações de temperatura externa.

Como silos de laboratório, foram utilizados potes de polipropileno, com capacidade de $2 \mathrm{~kg}$, em que foram colocadas as silagens a serem analisadas. Foram utilizados três potes para cada tratamento. Os potes foram vedados com tule, para impedir a entrada de insetos. As medidas de temperatura foram realizadas às $8,11,14 \mathrm{e} 17 \mathrm{~h}$, com uso de termômetro digital, modelo Gulterm 1001. A leitura dos valores de $\mathrm{pH}$ foi feita com potenciômetro digital. $\mathrm{O} \mathrm{pH}$ das silagens foi obtido duas vezes ao dia, às $11 \mathrm{e} 17 \mathrm{~h}$, conforme Cherney \& Cherney (2003). Para determinação das perdas totais, os silos foram pesados diariamente às $15 \mathrm{~h}$.

O delineamento experimental utilizado, na avaliação da estabilidade aeróbia, foi inteiramente casualizado, com três repetições, em esquema de parcelas subdivididas, em que as parcelas foram constituídas pelos tratamentos, e as subparcelas pelos tempos de medida.

No experimento de degradabilidade, foram utilizados três bovinos da raça Holandesa, com peso-vivo médio de $480 \mathrm{~kg}$, portadores de cânula ruminal. Os animais foram adaptados à alimentação durante cinco dias, antes da incubação ruminal, e foram alimentados duas vezes ao dia, às $8 \mathrm{e} 16 \mathrm{~h}$. A dieta era composta pela silagem de milho, como volumoso, e concentrado à base de milho e farelo de soja.

A degradabilidade ruminal da matéria seca e da proteína bruta, das silagens incubadas, e suas respectivas taxas de degradação foram estimadas pela técnica in situ do saco de náilon, segundo Ørskov et al. (1980). Para o amido, não foi calculada a degradabilidade, mas foi determinada a curva de desaparecimento após 24 horas de incubação no rúmen. Os sacos de náilon, utilizados para incubação ruminal, tinham dimensões de $10 \times 20 \mathrm{~cm}$, com abertura de poros de $53 \mu \mathrm{m}$. Aproximadamente $7 \mathrm{~g}$ de amostra (base MS) foram acondicionados em cada saco, e foram fechados e atados com elástico.

Durante a incubação, os sacos (seis por animal) foram presos a uma barra cilíndrica de ferro inoxidável (600 g), suspensa por um fio de náilon de $60 \mathrm{~cm}$ de comprimento. Os tempos de incubação empregados foram de $0,6,12$, 24,48 e 72 horas.
A incubação foi realizada sempre no mesmo horário, e os sacos foram retirados nos tempos determinados. Após a remoção, foram lavados em água corrente, em baldes, até que ela se apresentasse cristalina. O tempo zero não foi incubado, apenas lavado e congelado. Após serem lavados, os sacos foram submetidos à secagem em estufa de ventilação forçada, a $55^{\circ} \mathrm{C}$ por 72 horas. A percentagem de desaparecimento da matéria seca e da proteína bruta, por tempo de incubação, foi calculada pela proporção de resíduo nos sacos, após a incubação ruminal. A partir dos valores obtidos, foi calculada a curva de desaparecimento das frações MS e PB.

A degradabilidade da matéria seca e proteína bruta foi calculada por meio da equação descrita por Mehrez \& Ørskov (1977): $\mathrm{p}=\mathrm{a}+\mathrm{b}^{*}\left(1-\mathrm{e}^{-\mathrm{c}^{*} \mathrm{t}}\right)$, em que: $\mathrm{p}$ é a degradação potencial no tempo t; a é a porção prontamente degradável no rúmen; b é a fração insolúvel, mas potencialmente degradável; c é a taxa constante de degradabilidade da fração b; t é o tempo de incubação; $a+b \leq 100$. Os parâmetros não-lineares $a, b$ e c foram estimados pelos procedimentos iterativos de quadrados mínimos. As degradabilidades efetivas da matéria seca e da proteína bruta foram calculadas por meio da equação descrita por Ørskov \& McDonald (1979): degradabilidade efetiva $=\mathrm{a}+(\mathrm{b} * \mathrm{c}) /(\mathrm{c}+\mathrm{k})$, em que: $\mathrm{k}$ é a taxa estimada da passagem de sólidos no rúmen. Os demais parâmetros estão descritos na equação anterior.

Como não foi determinada a taxa de passagem real, a degradabilidade efetiva para cada alimento foi estimada com taxas de passagem de sólidos de 2,5 e $8 \%$ por hora, valores atribuídos, respectivamente, aos níveis baixo, médio e alto de ingestão alimentar (AFRC, 1993).

Os dados foram arranjados em blocos ao acaso, com três repetições para cada tratamento. Os resultados obtidos foram submetidos à análise de variância e comparados pelo teste de Tukey, a 5\% de probabilidade, com uso do sistema para análises estatísticas e genéticas (UFV, 1997).

\section{Resultados e Discussão}

Na Tabela 1, é mostrada a composição química dos aditivos adicionados aos grãos de milho, no momento da ensilagem. Destaca-se o alto teor de óleo observado nos grãos de girassol. Segundo Castiglioni et al. (1994), os grãos de girassol apresentam teor de EE entre 35 e $45 \%$, e há grande variação entre cultivares. A cultivar de girassol utilizada no presente estudo foi a IAC-Uruguai. 
O teor de amido, nos grãos de soja e de girassol, foi bastante baixo. No entanto, especialmente em relação ao teor de $\mathrm{PB}$, verificou-se que a adição de grãos de girassol ou de soja pode melhorar a silagem de milho.

Na Tabela 2, são mostrados os valores para a composição química das silagens, nos diferentes tratamentos, antes e após a ensilagem.

Verificou-se que não houve diferença significativa para os teores de MS, MO e MM entre os tratamentos, antes e após a ensilagem. O teor médio de MS das silagens foi de $64,6 \%$, considerado como adequado para a fermentação dos grãos (Jobim et al., 2001; Costa et al., 2004).

Para os teores de EE, PB e amido, houve efeito da adição dos grãos de soja, ou de girassol, e de uréia, o que é explicado pela composição química dos aditivos. O teor de EE, nas silagens, elevou-se em 5,1 e 6,7 pontos percentuais, em relação à silagem de grãos de milho puro, respectivamente na SMS e SMG, enquanto a adição de uréia não mostrou efeito sobre esta variável.

Em relação ao teor de $\mathrm{PB}$, verificou-se que não houve diferença, entre os tratamentos, para os grãos antes e após a armazenagem. Isso evidencia a boa qualidade de conservação das silagens e as reduzidas perdas deste nutriente. Entre tratamentos, constatou-se que houve aumento no teor protéico com a adição de soja ou uréia, sem diferença entre a silagem com grãos de girassol e grãos de milho puro.

O teor de amido nas silagens foi reduzido com a adição de grãos de soja ou de girassol, fato atribuído ao teor desse componente nesses grãos (Tabela 1). A adição de uréia não afetou esta variável.

As silagens de milho puro e de milho com uréia apresentaram os maiores valores para a fração prontamente solúvel (a) de MS, e não apresentaram diferença significativa entre si. No entanto, a SMS apresentou valor intermediário e diferente das demais silagens (Tabela 3 ). A redução na fração a pode ter ocorrido em razão do alto teor de EE dos grãos de girassol e de soja, o que dificultou a solubilização de alguns componentes da MS. Segundo Valadares Filho \& Pina (2006), os lipídios podem alterar a fermentação ruminal, o que depende da quantidade e da fonte, e os lipídios insaturados apresentam mais efeito que os saturados.

Para a fração potencialmente degradável no rúmen (b), houve diferença entre tratamentos; a SGM e SMU apresentaram os menores valores e não diferiram entre si. A silagem de milho com girassol apresentou maior valor entre as silagens, o que é explicado pela menor fração a. A taxa de degradação da fração b da MS foi menor para SMS e SMG, e apresentaram diferenças em relação às outras silagens.

Tabela 1. Composição química dos grãos de milho, de soja e de girassol adicionados às silagens ${ }^{(1)}$.

\begin{tabular}{lcccccc}
\hline Grão & MS (\%) & MO (\%) & MM (\%) & EE (\%) & PB (\%) & Amido (\%) \\
\hline Milho & 86,5 & 93,4 & 6,6 & 4,6 & 9,6 & 51,8 \\
Soja & 91,7 & 91,4 & 8,6 & 21,8 & 34,9 & 3,8 \\
Girassol & 94,9 & 94,3 & 5,7 & 51,3 & 15,9 & 0,2 \\
\hline
\end{tabular}

${ }^{(1)}$ MS, matéria seca; MO, matéria orgânica; MM, matéria mineral; EE, extrato etéreo; PB, proteína bruta.

Tabela 2. Composição química dos grãos, antes e após a ensilagem ${ }^{(1)}$.

\begin{tabular}{|c|c|c|c|c|c|c|}
\hline Material & MS (\%) & $\mathrm{MO}(\%)$ & MM (\%) & EE $(\%)$ & PB (\%) & Amido (\%) \\
\hline & \multicolumn{6}{|c|}{ Antes da ensilagem } \\
\hline Grãos de milho (GM) & 64,3 & 94,6 & 5,4 & $4,7 \mathrm{c}$ & $9,5 b$ & $74,1 \mathrm{a}$ \\
\hline $\mathrm{GM}+$ soja & 66,4 & 93,2 & 6,8 & $16,1 \mathrm{a}$ & $16,1 \mathrm{a}$ & $51,8 \mathrm{c}$ \\
\hline GM + girassol & 67,1 & 93,8 & 6,2 & $11,5 b$ & $13,4 b$ & $66,4 \mathrm{~b}$ \\
\hline $\mathrm{GM}+$ uréia & 65,3 & 93,7 & 6,3 & $4,5 \mathrm{c}$ & $19,3 \mathrm{a}$ & $59,3 \mathrm{~b}$ \\
\hline & \multicolumn{6}{|c|}{ Silagens } \\
\hline SGM & 62,1 & 94,5 & 5,5 & $5,2 \mathrm{c}$ & $10,1 \mathrm{~b}$ & $64,2 \mathrm{~b}$ \\
\hline SMS & 65,6 & 93,0 & 7,0 & $10,3 b$ & $17,7 \mathrm{a}$ & $51,2 \mathrm{c}$ \\
\hline SMG & 65,0 & 95,1 & 4,9 & $11,9 b$ & $10,9 b$ & $56,8 \mathrm{bc}$ \\
\hline SMU & 65,7 & 94,4 & 5,6 & $4,9 \mathrm{c}$ & $20,2 \mathrm{a}$ & $59,3 \mathrm{~b}$ \\
\hline CV (\%) & 5,2 & 3,8 & 4,1 & 8,7 & 9,6 & 13,4 \\
\hline
\end{tabular}

(1) Valores seguidos por letras iguais, nas colunas, não diferem entre si pelo teste de Tukey, a 5\% de probabilidade; MS, matéria seca; MO, matéria orgânica; MM, matéria mineral; EE, extrato etéreo; PB, proteína bruta; SGM, silagem de grãos de milho; SMS, silagem de grãos de milho + grãos de soja (20\%); SMG, silagem de grãos de milho + grãos de girassol (20\%); SMU, silagem de grãos de milho + uréia (1\% da matéria úmida). 
A degradabilidade potencial (DP) diferiu significativamente entre as silagens, com valor médio de $90,06 \%$. A SMG apresentou o menor valor e diferiu da silagem com adição de soja. O valor obtido no presente estudo, para a DP da SGM, foi inferior ao observado por Jobim et al. (1999), que registraram DP de $97,53 \%$ em silagem de grãos úmidos de milho.

Os valores para DE, nas taxas de passagem de 2,5 e $8 \%$ por hora, apresentaram diferença significativa entre tratamentos. A maior DE da MS foi observada para as silagens SGM e SMU, independentemente da taxa de passagem utilizada. Porém, a silagem com adição de grãos de girassol mostrou a menor DE da MS, que chegou a ser $26,6 \%$, em relação à SGM pura, na taxa de passagem $8 \%$ por hora. A DE média $(86 \%)$ da MS da SGM, observada no presente estudo, foi superior à registrada por Jobim et al. (1999), que foi de 72,73\% na taxa de passagem de 5\% por hora. Essas diferenças podem ser atribuídas à composição química dos grãos ensilados, que é dependente do híbrido de milho e da tecnologia de ensilagem utilizadas.

As silagens SGM e SMU apresentaram maior fração da proteína bruta prontamente solúvel no rúmen, enquanto SMS e SMG apresentaram resultados menores e semelhantes (Tabela 3). O resultado da fração a da PB da SMU é explicado pela alta solubilidade da uréia.

De maneira inversa, para a fração da proteína potencialmente degradável no rúmen (b), as silagens de milho com soja e milho com girassol apresentaram maiores valores (43,47 e 37,28\%, respectivamente), em comparação às silagens de milho $(14,45 \%)$ e de milho com uréia $(9,52 \%)$. Esta maior fração b das silagens de milho com soja e milho com girassol deve-se, em parte, a seus menores valores da fração a e demonstra que as silagens de milho com soja e milho com girassol apresentam taxa de degradação mais lenta do que as silagens de milho puro e de milho com uréia, possivelmente em razão do maior teor de EE (Tabela 1).

A taxa de degradação (c) da PB apresentou diferença significativa entre as silagens, e foi superior para SGM, que não diferiu da SMU, com valores inferiores para as SMS e SMG.

Para a DP da proteína bruta, a SMG apresentou o menor valor em relação às demais silagens, que apresentaram valores similares entre si. A DE da proteína bruta foi maior para a SMU, nas diferentes taxas de passagem, provavelmente em razão da alta solubilidade da uréia. As SMS e SMG apresentaram menores valores para todas as taxas de passagem, o que pode ser atribuído à própria proteína dos grãos de girassol e de soja e ao aumento no teor de EE dessas silagens.

A Figura 1 mostra o desaparecimento do amido das silagens, no ambiente ruminal, no período de 24 horas de incubação. Verificou-se que o amido da SGM apresentou maior $(\mathrm{p}<0,05)$ velocidade de desaparecimento e maior percentual de amido desaparecido no rúmen $(68,4 \%)$. No entanto, a SMG apresentou menor taxa de desaparecimento e menor desaparecimento total $(53,41 \%)$, em relação às demais silagens. Esse comportamento pode ser atribuído, em parte, ao maior teor de EE da SMG que dificulta a ação dos microrganismos do rúmen sobre o amido. De acordo com Valadares Filho \& Pina (2006), os lipídios não afetam

Tabela 3. Parâmetros da degradabilidade potencial e degradabilidade efetiva da matéria seca e da proteína bruta de silagens de grãos de milho(1).

\begin{tabular}{|c|c|c|c|c|c|c|c|}
\hline \multirow[t]{2}{*}{ Silagem } & \multirow[t]{2}{*}{$\mathrm{a}$} & \multirow[t]{2}{*}{$\mathrm{b}$} & \multirow[t]{2}{*}{ c $(\% / h)$} & \multirow[t]{2}{*}{ DP } & \multicolumn{3}{|c|}{$\mathrm{DE}$} \\
\hline & & & & & $2 \% / \mathrm{h}$ & $5 \% / h$ & $8 \% / h$ \\
\hline & & & & Matéria & & & \\
\hline SGM & $63,41 \mathrm{a}$ & $28,03 \mathrm{c}$ & $0,19 \mathrm{a}$ & $91,43 \mathrm{ab}$ & $88,86 a$ & $85,78 \mathrm{a}$ & $83,36 a$ \\
\hline SMS & $41,26 b$ & $52,20 \mathrm{~b}$ & $0,06 b$ & $93,46 a$ & $80,51 b$ & $69,93 b$ & $63,86 b$ \\
\hline SMG & $26,49 c$ & $58,26 a$ & $0,09 b$ & $84,75 b$ & $73,81 \mathrm{c}$ & $63,42 \mathrm{c}$ & $56,77 \mathrm{c}$ \\
\hline SMU & $60,23 \mathrm{a}$ & $30,38 \mathrm{c}$ & $0,17 \mathrm{a}$ & $90,61 \mathrm{ab}$ & $87,34 a$ & $83,57 \mathrm{a}$ & $80,73 a$ \\
\hline & & & & Proteína & & & \\
\hline SGM & $82,08 \mathrm{a}$ & $14,45 b$ & $0,28 \mathrm{a}$ & $96,53 \mathrm{a}$ & $95,52 \mathrm{a}$ & $94,25 \mathrm{a}$ & $93,20 \mathrm{a}$ \\
\hline SMS & $55,19 b$ & $43,47 a$ & $0,04 b$ & $98,67 \mathrm{a}$ & $84,99 b$ & $75,48 \mathrm{c}$ & $70,59 \mathrm{c}$ \\
\hline SMG & $55,47 \mathrm{~b}$ & $37,28 \mathrm{a}$ & $0,08 \mathrm{~b}$ & $92,75 b$ & $85,39 b$ & $78,62 b$ & $74,37 b$ \\
\hline SMU & $88,31 \mathrm{a}$ & $9,52 b$ & $0,18 \mathrm{ab}$ & $97,84 a$ & $96,91 \mathrm{a}$ & $95,82 \mathrm{a}$ & $94,98 \mathrm{a}$ \\
\hline
\end{tabular}

${ }^{(1)}$ Valores seguidos por letras iguais, nas colunas, não diferem entre si pelo teste de Tukey, a 5\% de probabilidade; DP, degradabilidade potencial; $\mathrm{DE}$, degradabilidade efetiva das silagens para taxas de passagem de 2,5 e $8 \% / \mathrm{h}$; a, fração prontamente solúvel no rúmen; b, fração insolúvel potencialmente degradável no rúmen; c, taxa de degradação da fração b (\%/h); SGM, silagem de grãos de milho; SMS, silagem de grãos de milho + grãos de soja (20\%); SMG, silagem de grãos de milho + grãos de girassol (20\%); SMU, silagem de grãos de milho + uréia (1\% da matéria úmida). 
a fermentação ruminal do amido. Contudo, é possível que o alto teor de EE da silagem (11,9\%) tenha causado uma barreira física para o desaparecimento do amido dos sacos de náilon incubados. Também, de acordo com Palmquist \& Mattos (2006), certos ácidos graxos, especialmente os poliinsaturados, são tóxicos aos microrganismos ruminais.

Na Tabela 4, são mostrados os dados referentes ao estudo da estabilidade em aerobiose das silagens. A silagem SMU mostrou maior estabilidade aeróbia, possivelmente em razão do efeito da uréia sobre o desenvolvimento dos microrganismos. Segundo Dolberg (1992), a adição de uréia, em silagens, exerce efeito no controle de amônia. Porém, a SMG mostrou maior velocidade de deterioração, com altos valores de temperatura na massa e elevados valores de $\mathrm{pH}$. As perdas totais no período de avaliação da estabilidade foram elevadas, com média de 12,26\%.

A Figura 2 mostra a evolução da temperatura, durante a exposição ao ar. Logo após a abertura dos silos, as silagens apresentaram temperaturas similares à temperatura ambiente, o que é evidência de baixa atividade de microrganismos. A temperatura ambiente não sofreu variações significativas no decorrer do tempo. A silagem que apresentou maior estabilidade, com valores próximos ao da temperatura ambiente, foi a SMU.

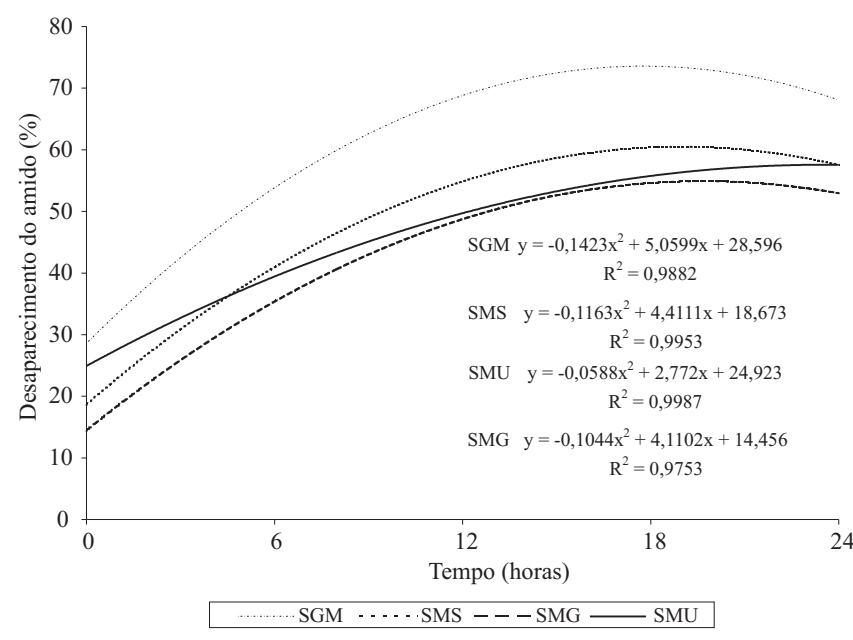

Figura 1. Desaparecimento do amido de silagens de grãos de milho, no ambiente ruminal, no período de 24 horas de incubação.
A SMS permaneceu estável até de 34 horas, com posterior aumento em sua temperatura. A SMG foi a que apresentou maior temperatura entre as silagens, com aumento gradativo a partir de 50 horas.

A Figura 3 mostra que, logo após o início do processo de deterioração, a SMU apresentou valor de $\mathrm{pH}$ alto, em relação às demais silagens, seguido de queda, com estabilidade por longo período. Assim, a SMU apresentou menores variações de $\mathrm{pH}$, durante o decorrer do tempo.

Tabela 4. Temperatura, $\mathrm{pH}$ e perda de matéria seca (PMS) associados à estabilidade aeróbia de silagens de grãos de milho (SGM), milho e uréia (SMU), milho e girassol (SMG) e silagem de milho com soja (SMS).

\begin{tabular}{lcccc}
\hline Variável & \multicolumn{4}{c}{ Tratamentos } \\
\cline { 2 - 5 } & SGM & SMU & SMG & SMS \\
\hline № H $2{ }^{\circ} \mathrm{C}$ & $20 \mathrm{~b}$ & $26 \mathrm{a}$ & $15 \mathrm{c}$ & $20 \mathrm{~b}$ \\
TMáx & $33,3 \mathrm{c}$ & $30,3 \mathrm{c}$ & $42,1 \mathrm{a}$ & $37,9 \mathrm{~b}$ \\
№ H TMáx & $122 \mathrm{a}$ & $74 \mathrm{c}$ & $107 \mathrm{~b}$ & $104 \mathrm{~b}$ \\
№ D TMáx & 6 & 5 & 5 & 5 \\
pH Máx & $7,5 \mathrm{a}$ & $5,4 \mathrm{c}$ & $7,4 \mathrm{a}$ & $6,0 \mathrm{~b}$ \\
№ H pH Máx & $106 \mathrm{a}$ & $2 \mathrm{~b}$ & $2 \mathrm{~b}$ & $106 \mathrm{a}$ \\
№ D pH Máx & $5 \mathrm{a}$ & $1 \mathrm{~b}$ & $1 \mathrm{~b}$ & $5 \mathrm{a}$ \\
PMS & $13,35 \mathrm{a}$ & $9,25 \mathrm{~b}$ & $14,56 \mathrm{a}$ & $11,88 \mathrm{a}$ \\
\hline
\end{tabular}

(1)Valores seguidos por letras iguais, na linha, não diferem entre si pelo teste de Tukey, a $5 \%$ de probabilidade; № $\mathrm{H} 2^{\circ} \mathrm{C}$, número de horas para elevação da temperatura em $2^{\circ} \mathrm{C}$ acima da temperatura ambiente; Tmáx, temperatura máxima atingida pela massa $\left({ }^{\circ} \mathrm{C}\right)$; № $\mathrm{H}$ Tmáx, número de horas para elevação da temperatura em $2^{\circ} \mathrm{C}$; № D Tmáx, número de dias para atingir a temperatura máxima; pH Máx, pH máximo alcançado; № $\mathrm{H}$ pH Máx, número de horas para atingir o pH máximo; № $\mathrm{D}$ pH Máx, número de dias para se atingir o pH máximo.

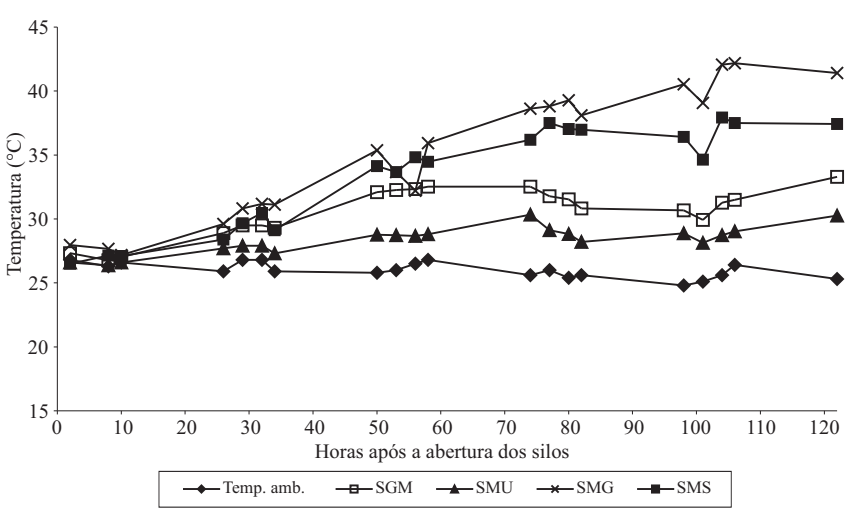

Figura 2. Temperatura das silagens de milho puro (SGM), silagem de milho com uréia (SMU), silagem de milho com girassol (SMG), silagem de milho com soja (SMS) e temperatura ambiente (Temp amb), em função do tempo em horas. 


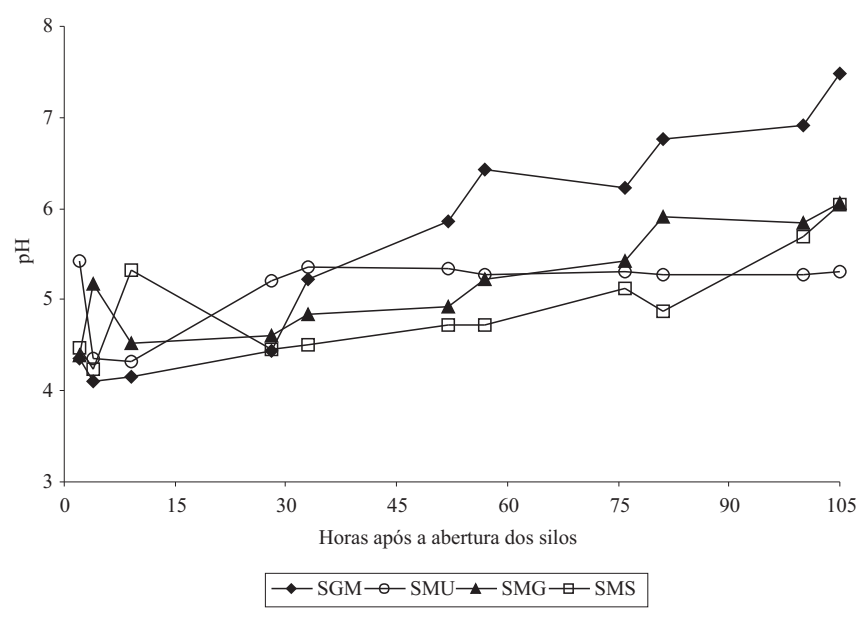

Figura 3. Variações do pH, em função do tempo e exposição ao ar, para silagens de milho (SGM), milho e uréia (SMU), milho e girassol (SMG) e silagem de milho com soja (SMS).

\section{Conclusões}

1. A adição de grãos de girassol, de soja ou uréia, na silagem de grãos úmidos de milho, melhora a composição químico-bromatológica.

2. A adição de $20 \%$ de grãos de girassol ou de grãos de soja, à silagem de grãos úmidos de milho, reduz a degradabilidade efetiva da matéria seca e da proteína bruta.

3. A adição de uréia à silagem de grãos úmidos de milho diminui as perdas de matéria seca e melhora sua estabilidade em aerobiose.

\section{Referências}

AGRICULTURAL AND FOOD RESEARCH COUNCIL. Energy and protein requeriments of ruminants. Wallingford: $C A B$ International, 1993. 159p.

BERNDT, A.; HENRIQUE, W.; LANNA, D.P.D.; LEME, P.R.; ALLEONI, G.F. Milho úmido, bagaço de cana e silagem de milho em dietas de alto teor de concentrado. 2. Composição corporal e taxa de deposição de tecidos. Revista Brasileira de Zootecnia, v.31, p.2105-2112, 2002.

CASTIGLIONI, V.B.R.; BALLA, A.; CASTRO, C.; SILVEIRA, J.M. Fases de desenvolvimento da planta do girassol. Londrina: Embrapa-CNPSo, 1994. 24p. (Embrapa-CNPSo. Documentos, 59).

CHERNEY, J.H.; CHERNEY, D.J.R. Assessing silage quality. In: BUXTOU, D.R.; MUCK, R.E.; HARISSON, J.H. Silage science and technology. Madison: ASA, CSSA, SSSA, 2003. p.141-198.

COSTA, C.; MEIRELLES, P.R.L.; REIS, W. Silagem de grãos úmidos na alimentação animal. In: SIMPÓSIO SOBRE PRODUÇÃO
E UTILIZAÇÃO DE FORRAGENS CONSERVADAS, 2., 2004, Maringá. Anais. Maringá: Universidade Federal de Maringá, 2004. p.133-160.

DEMARQUILLY, C. Quelles méthodes: pour quels objetifs? In: Colloque maïs ensilage, 1996, Nantes, France. Nantes: Association Générale des Producteurs de Maïs, 1996. p.87-91.

DOLBERG, F. Progressos na utilização de resíduos de culturas tratadas com uréia-amônia. In: SIMPÓSIO INTERNACIONAL EM RUMINANTES, 1992, Lavras. Anais. Lavras: Ufla, 1992. p.322-337.

JOBIM, C.C.; BARRIM, G.M.; REIS, W.; GONÇALVES, G.D.; CECATO, U. Composição química de silagem de grãos úmidos de milho com adição de grãos de soja. In: REUNIÃO ANUAL DA SOCIEDADE BRASILEIRA DE ZOOTECNIA, 39., 2002, Recife. Anais. Recife: Sociedade Brasileira de Zootecnia, 2002. 1 CD-ROM. JOBIM, C.C.; CECATO, U.; CANTO, M.W. Utilização de silagem de grãos de cereais na alimentação animal. In: SIMPÓSIO SOBRE PRODUÇÃO E UTILIZAÇÃO DE FORRAGENS CONSERVADAS, 2001, Maringá. Anais. Maringá: UEM, 2001. p.146-176.

JOBIM, C.C.; REIS, R.A. Produção e utilização de silagem de grãos úmidos de milho. In: REUNIÃ̃O ANUAL DA SOCIEDADE BRASILEIRA DE ZOOTECNIA, 38., 2001, Piracicaba. Anais. Piracicaba: Sociedade Brasileira de Zootecnia, 2001. p.912-927.

JOBIM, C.C.; REIS, R.A.; RODRIGUES, L.R.A. Avaliação da silagem de grãos úmidos de milho. Pesquisa Agropecuária Brasileira, v.32, p.311-315,1997.

JOBIM, C.C.; REIS, R.A.; SHOKEN-ITURRINO, R.P.; ROSA, B. Desenvolvimento de microrganismos durante a utilização de silagem de grãos úmidos de milho e de espigas de milho sem brácteas. Acta Scientiarum, v.21, p.671-676, 1999.

KUNG JÚNIOR, L. Silage fermentation and additives. In: SCIENCE AND TECHNOLOGY IN THE FEED INDUSTRY, 17., 2001, Nottingham. Proceedings. Nottingham: Nottingham University Press, 2001. p.145-159.

MEHREZ, A.Z.; ØRSKOV, E.R. A study of the artificial fibre bag technique for determining the digestibility of feeds in the rumen. Journal of Agriculture Science, v.88, p.645-650, 1977.

ØRSKOV, E.R.; HOVELL. F.D.B.; MOULD, F. The use of the nylon technique for the evaluation of feedstuffs. Tropical Animal Production, v.5, p.195-213, 1980.

ØRSKOV, E.R.; McDONALD, I. The estimation of protein degradability in the rumen from incubation measurements weighted according to rate passage. Journal of Agricultural Science, v.92, p.499-502, 1979.

PALMQUIST, D.L.; MATTOS, W.R.S. Metabolismo de lipídios. In: BERCHIELLI, T.T.; PIRES, A.V.; OLIVEIRA, S.G. (Ed.). Nutrição de ruminantes. Jaboticabal: Funep, 2006. p.287-309.

PEREIRA, J.R.A.; ROSSI JÚNIOR, P. Manual prático de avaliação nutricional de alimentos. Piracicaba: Fealq, 1994. 25p.

REIS, W.; JOBIM, C.C.; MACEDO, F.A.F.; MARTINS, E.N.; CECATO, U. Características da carcaça de cordeiros alimentados com dietas contendo grãos de milho conservados em diferentes formas. Revista Brasileira de Zootecnia, v.30, p.1308-1315, 2001. 
SILVA, D.J.; QUEIROZ, A.C. Análise de alimentos: métodos químicos e biológicos. 3.ed. Viçosa: UFV, 2002. 235p.

THEURER, C.B.; HUBER, J.T.; DELGADO-ELORDUY, A.; WANDERLEY, R. Invited review: summary of steam-flaking corn or sorghum grain for lactating dairy cows. Journal of Dairy Science, v.82, p.1950-1959,1999.
UNIVERSIDADE FEDERAL DE VIÇOSA. SAEG: sistemas de análises estatísticas e genéticas. Viçosa: UFV, 1997. (Versão 7.0).

VALADARES FILHO, S.C.; PINA, D.S. Fermentação ruminal. In: BERCHIELLI, T.T.; PIRES, A.V.; OLIVEIRA, S.G. (Ed.). Nutrição de ruminantes. Jaboticabal: Funep, 2006. p.151-179.

Recebido em 31 de janeiro de 2008 e aprovado em 16 de maio de 2008 